\title{
RELEVANSI HUKUM PROGRESIF TERHADAP HUKUM ISLAM
}

\author{
Muhammad Samsuri \\ Fakultas Syari’ah Institut Islam Mamba’ul 'Ulum Surakarta \\ e-mail: muhsamsuri1@yahoo.com
}

\begin{abstract}
One of the most interesting legal ideas in the current legal literature of Indonesia is progressive law. This is because progressive law has challenged the existence of modern law which has so far been considered established in punishment. The law reveals the veil and overthrows the failures of modern law based on positiveistic, legalistic and linear philosophy to address issues developed in accordance with the law as a matter of human and humanity. Progressive law contains the liberating spirit of liberation from the legalistic and linear conventional legal conviction. Running a law is not merely textual legislation but in running the law must be by determination, empathy, dedication, commitment to the suffering of the nation to dare to find another way to prosper human. Progressive law starts from a basic assumption, law is an institution that aims to bring people to a life of justice, prosperity and make people happy. The flexibility of the development of Islamic legal thought is highly relevant to introducing the ethos of progresivism in the dynamics and crystallization of Islamic law. The implication of this progressive mode of thinking is the liberation of mankind from mythological, passive and aggressive-conservative things. On the basis of this progressive ethos, it is recognized the capacity of the free will, free act.
\end{abstract}

Keywords: progressive law, Islamic Law, welfare

\section{PENDAHULUAN}

Gagasan hukum progresif berawal dari masalah penegakkan hukum di pengadilan yang merupakan representasi dari penegakan hukum dinilai banyak memberikan putusanputusan yang tidak mencerminkan keadilan. Dalam menghadapi problematik ini Satjipto Rahardjo memunculkan gagasan hukum progresif. Hukum hendaknya mampu mengikuti perkembangan jaman, mampu menjawab problematika yang berkembang dalam masyarakat, serta mampu melayani masyarakat dengan menyandarkan pada aspek moralitas dari sumber daya aparat penegak hukum sendiri. Gagasan ini muncul sebagai respon atas paradigma positivistik yang membuat ambruknya hukum. ${ }^{1}$

Tokoh yang melahirkan teori hukum progresif ini adalah Satjipto Rahardjo, teori ini berawal dari keprihatinan beliau terhadap kepurukan hukum di Indonesia, beberapa kritiknya yang sering dilontarkan baik berupa wacana lisan maupun tulisan antara lain dikatakan bahwa: "Hukum itu sudah cacat sejak dilahirkan, hal ini sejatinya adalah sebuah tragedi hukum.Masyarakat diatur hukum yang penuh cacat, karena ketidakmampuannya untuk merumuskan secara tepat hal-hal yang ada dalam masyarakat. Akibatnya masyarakat diatur oleh hukum yang sudah cacat sejak lahir."2 Selanjutnya dalam tulisan berikut akan dibahas bagaimana relevansi hukum progresif terhadap hukum Islam.

\footnotetext{
${ }^{1}$ Satjipto Rahardjo, 2008, Membedah Hukum Progresif, Jakarta, Penerbit Buku Kompas, hal.ix-x ${ }^{2}$ Satjipto Rahardjo, 2006, Hukum dalam Jagat Ketertiban, Jakarta, Uki Press, hal..iv
} 


\section{PEMBAHASAN}

\section{Pengertian Hukum Progresif}

Progresif adalah kata yang berasal dari bahasa asing (Inggris) yang asal katanya adalah progress yang artinya maju. Progressive adalah kata sifat, jadi sesuatu yang bersifat maju. Hukum Progresif berarti hukum yang bersifat maju. Pengertian progresif secara harfiah ialah, favouring new, modern ideas, happening or developing steadily (menyokong ke arah yang baru, gagasan modern, peristiwa atau perkembangan yang mantap), atau berhasrat maju, selalu (lebih) maju, meningkat. ${ }^{3}$

Hukum Progresif berarti hukum yang bersifat maju. Istilah hukum progresif, diperkenalkan oleh Satjipto Rahardjo, yang dilandasi filosofi hukum yang sebenarnya, adalah "Hukum untuk manusia, bukan manusia untuk hukum". Hukum bertugas melayani, bukan sebaliknya. ${ }^{4}$ Satjipto Rahardjo merasa prihatin dengan rendahnya kontribusi ilmu hukum dalam mencerahkan bangsa Indonesia, dalam mengatasi krisis, termasuk krisis dalam bidang hukum itu sendiri. Adapun pengertian hukum progresif, adalah mengubah secara cepat, melakukan pembalikan yang mendasar dalam teori dan praksis hukum, serta melakukan berbagai terobosan. Pembebasan tersebut di dasarkan pada prinsip bahwa hukum adalah untuk manusia dan bukan sebaliknya dan hukum itu tidak ada untuk dirinya sendiri, melainkan untuk sesuatu yang lebih luas yaitu untuk harga diri manusia, kebahagiaan, kesejahteraan, dan kemuliaan manusia. ${ }^{5}$

Pengertian sebagaimana dikemukakan oleh Satjipto Rahardjo tersebut berarti hukum progresif adalah serangkaian tindakan yang radikal, dengan mengubah sistem hukum (termasuk merubah peraturan-peraturan hukum bila perlu) agar hukum lebih berguna, terutama dalam mengangkat harga diri serta menjamin kebahagiaan dan kesejahteraan manusia. Secara lebih sederhana hukum progresif adalah hukum yang melakukan pembebasan, baik dalam cara berpikir maupun bertindak dalam hukum, sehingga mampu membiarkan hukum itu mengalir saja untuk menuntaskan tugasnya mengabdi kepada manusia dan kemanusiaan. Jadi tidak ada rekayasa atau keberpihakan dalam menegakkan hukum. Sebab menurutnya, hukum bertujuan untuk menciptakan keadilan dan kesejahteraan bagi semua rakyat. ${ }^{6}$

Satjipto Rahardjo mencoba menyoroti kondisi di atas ke dalam situasi ilmu-ilmu sosial, termasuk ilmu hukum, meski tidak sedramatis dalam ilmu fisika, tetapi pada dasarnya tejadi perubahan yang fenomenal mengenai hukum yang dirumuskannya dengan kalimat dari yang sederhana menjadi rumit dan dari yang terkotak-kotak menjadi satu kesatuan. Inilah yang disebutnya sebagai pandangan holistik dalam ilmu (hukum). Pandangan holistik tersebut memberikan kesadaran visioner bahwa sesuatu dalam tatanan tertentu memiliki bagian yang saling berkaitan baik dengan bagian lainnya atau dengan keseluruhannya.

Hukum progresif bermakna hukum yang peduli terhadap kemanusiaan sehingga bukan sebatas dogmatis belaka. Secara spesifik hukum progresif antara lain bisa disebut sebagai hukum yang pro rakyat dan hukum yang berkeadilan. Konsep hukum progresif adalah hukum tidak ada untuk kepentingannya sendiri, melainkan untuk suatu tujuan yang

\footnotetext{
${ }^{3}$ Pius A Partanto dan M. Dahlan Al Barry, 2001, Kamus Ilmiah Populer, Surabaya, Arkola, hal.628.

${ }^{4}$ Suteki, 2015, Masa Depan Hukum Progresif, Yogyakarta, Thafa Media, hal. 3

${ }^{5}$ Satjipto Rahardjo, 2008, Membedah Hukum Progresif, Jakarta, Penerbit Buku Kompas, hal. 154

${ }^{6}$ Faisal, 2015, Pemaknaan Hukum Progresif, Yogyakarta, Thafa Media, hal. 23-24
} 
berada di luar dirinya. Oleh karena itu, hukum progresif meninggalkan tradisi analytical jurisprudence atau rechtsdogmatiek.Aliran-aliran tersebut hanya melihat ke dalam hukum dan membicarakan serta melakukan analisis ke dalam, khususnya hukum sebagai suatu bangunan peraturan yang dinilai sebagai sistematis dan logis. Hukum progresif bersifat responsif yang mana dalam responsif ini hukum akan selalu dikaitkan pada tujuan-tujuan di luar narasi tekstual hukum itu sendiri. ${ }^{7}$

\section{Karakter Hukum Progresif}

Kehadiran hukum dikaitkan pada tujuan sosialnya, maka hukum progresif juga dekat dengan sociological jurisprudence dari Roscoe Pound.Hukum progresif juga mengundang kritik terhadap sistem hukum yang liberal, karena hukum Indonesia pun turut mewarisi sistem tersebut. Satu moment perubahan yang monumental terjadi pada saat hukum pra modern menjadi modern.Disebut demikian karena hukum modern bergeser dari tempatnya sebagai institusi pencari keadilan menjadi institusi publik yang birokratis. Hukum yang mengikuti kehadiran hukum modern harus menjalani suatu perombakan total untuk disusun kembali menjadi institusi yang rasional dan birokratis. Akibatnya hanya peraturan yang dibuat oleh legislatiflah yang sah yang disebut sebagai hukum. Progresifisme hukum mengajarkan bahwa hukum bukan raja, tetapi alat untuk menjabarkan dasar kemanusiaan yang berfungsi memberikan rahmat kepada dunia dan manusia. Asumsi yang mendasari progresifisme hukum adalah pertama, hukum ada untuk manusia dan tidak untuk dirinya sendiri, kedua hukum selalu berada pada status law in the making dan tidak bersifat final, ketiga hukum adalah institusi yang bermoral kemanusiaan.

Berdasar asumsi-asumsi di atas maka karakter hukum progresif adalah: ${ }^{8}$

1. Bertujuan untuk kesejahteraan dan kebahagiaan manusia dan oleh karenanya memandang hukum selalu dalam proses menjadi (Law in the making)

2. Peka terhadap perubahan yang terjadi di masyarakat, baik lokal, nasional maupun global

3. Menolak status quo manakala menimbulkan dekadensi, suasana korup dan sangat merugikan kepentingan rakyat, sehingga menimbulkan perlawanan dan pemberontakan yang berujung pada penafsiran progresif terhadap hokum.

Hukum progresif bertolak dari pandangan bahwa hukum harus diingat sebagai suatu ilmu, oleh karenanya hukum tidak hanya dianggap selesai setelah tersusun sebagai peraturan perundang-undangan dengan kalimat yang telah tertata rapi dan sistematis, akan tetapi hukum harus selalu mengalami proses pemaknaan sebagai sebuah pendewasaan atau pematangan, sehingga dengan proses itulah hukum dapat menunjukkan jati dirinya sebagai sebuah ilmu, yaitu selalu berproses untuk mencari kebenaran. ${ }^{9}$

Fungsi hukum dan lembaga hukum dalam masyarakat, Satjipto Rahardjo mengemukakan bahwa: Pengkajian terhadap hukum dari sudut studi hukum dan masyarakat, selalu ingin menegaskan fungsi apa yang sesungguhnya dijalankan oleh hukum atau lembaga hukum itu di dalam masyarakat. Penegasan mengenai fungsi ini tidak hanya dilihat dari sudut

\footnotetext{
${ }^{7}$ Satjipto Raharjo, 2010, Hukum Progresif; Sebuah Sintesa Hukum di Indonesia, Yogyakarta, Genta Publishing, hal. 19

${ }^{8}$ Suteki, 2015, Masa Depan Hukum Progresif, Yogyakarta, Thafa Media, hal. 83

${ }^{9}$ Ari Wibowo, 2013, Mewujudkan Keadilan Melalui Penerapan Hukum Progresif, dalam Mahrus Ali (Editor), Membumikan Hukum Progresif, Yogyakarta, Aswaja Pressindo, Yogyakarta, hal. 7.
} 
ketentuan hokum yang mengaturnya, melainkan juga dari apa yang ditentukan oleh masyarakat sendiri mengenainya. ${ }^{10}$

Hukum merupakan mekanisme yang mengintegrasikan kekuatan-kekuatan dan proses-proses dalam masyarakat, dengan demikian maka pengadilan pastilah merupakan lembaga yang menjadi pendukung utama dari mekanisme itu, karena dalam lembaga inilah nantinya sengketa-sengketa yang terdapat dalam masyarakat tersebut akan diselesaikan, agar tidak terjadi pertentangan yang membahayakan keamanan dan ketertiban masyarakat. ${ }^{11}$ Hukum progresif dimulai dari suatu asumsi dasar, hukum adalah institusi yang bertujuan mengantarkan manusia kepada kehidupan yang adil, sejahtera dan membuat manusia bahagia.Hukum tersebut tidak mencerminkan hukum sebagai institusi yang mutlak serta final, melainkan ditentukan oleh kemampuannya untuk mengabdi kepada manusia. ${ }^{12}$

Menurut Bagir Manan, rumusan undang-undang yang bersifat umum, tidak pernah menampung secara pasti setiap peristiwa hukum. ${ }^{13}$ Hukum bukanlah sesuatu skema yang final (finie scheme), namun terus bergerak, berubah, mengikuti dinamika kehidupan manusia. ${ }^{14}$ Dalam perspektif hukum progresif, menolak rasionalitas diatas segalanya. Tujuan lebih besar dari hukum adalah keadilan dan kebahagiaan. Kebahagiaan inilah yang ditempatkan diatas segala-galanya. ${ }^{15}$ Karakteristik dari hukum progresif menurut Satjiptop Raharjo, yaitu: ${ }^{16}$

1. Hukum ada untuk mengabdi kepada masyarakat.

2. Hukum progresif akan tetap hidup karena hukum selalu berada pada statusnya sebagai law in the making dan tidak pernah bersifat final sepanjang manusia itu ada, maka hukum progresif akan terus hidup dalam menata kehidupan masyarakat.

3. Dalam hukum progresif selalu melekat etika dan moralitas kemanusiaan yang sangat kuat, yang akan memberikan respon terhadap perkembangan dan kebutuhan manusia serta mengabdi pada keadilan dan kesejahteraan.

Sehingga tujuan hukum untuk terciptanya suatu keadilan akan sulit terwujud atau setidak-tidaknya masih ada celah hukum yang dapat membuat proses penegakan hukum menjadi terhambat. Menyikapi kondisi ini maka teori hukum progresif yang digagas oleh Satjipto Rahardjo dapat dijadikan landasan berpijak untuk menjawab problematika.

\section{Dekonstruksi Hukum Islam: Paradigma Progresif}

Fleksibelitas perkembangan pemikiran hukum Islam di Indonesia sangat relevan dengan memperkenalkan etos progresivisme dalam dinamika dan kristalisasi hukum Islam.

\footnotetext{
${ }^{10}$ Satjipto Rahardjo, 1980, Hukum, Masyarakat dan Pembangunan, Cetakan kedua, Bandung, Alumni, hal.105-106. hal.106.

${ }^{11}$ Satjipto Rahardjo, 1980, Hukum, Masyarakat dan Pembangunan, Cetakan kedua, Bandung, Alumni,

${ }^{12}$ Satjipto Raharjo, 2010, Hukum Progresif; Sebuah Sintesa Hukum di Indonesia, Yogyakarta, Genta Publishing, hal.1

${ }^{13}$ Bagir Manan, 2005, Suatu Tinjauan terhadap Kekuasaan Kehakiman dalam Undang Undang Nomor 4 Tahun 2004, Mahkamah Agung RI, Jakarta, hal.209.

${ }^{14}$ Bagir Manan, 2005, Suatu Tinjauan terhadap Kekuasaan Kehakiman dalam Undang Undang Nomor 4 Tahun 2004, Mahkamah Agung RI, Jakarta, hal. VII

${ }^{15}$ Bagir Manan, 2005, Suatu Tinjauan terhadap Kekuasaan Kehakiman dalam Undang Undang Nomor 4 Tahun 2004, Mahkamah Agung RI, Jakarta hal. 12

${ }^{16}$ Ahmad Rifai, Penemuan Hukum Oleh Hakim Dalam Perspektif Hukum Progresif, Jakarta, Sinar Grafika. 2010, hal.46
} 
Implikasi dari corak pemikiran progresif ini adalah pembebasan manusia dari hal-hal yang bersifat mitologis, pasif maupun agresif-konservatif. Atas dasar etos progresif ini, diakui kapasitas manusia yang memiliki segenap kebebasan (free will, free act).

Dalam gagasan pembaruan pemikiran Hukum Islam di Indonesia, secara substantif, ada pembedaan pokok antara ajaran Islam yang bersifat qath'i (yang absolut) dan zhanni (yang relatif). Distingsi antara qath'i dengan zhanni begitu ditekankan, karena dalam hal inilah ruang untuk berijtihad itu terbuka. ${ }^{17}$

Meskipun secara keseluruhan al-Qur'an bersifat qath'i al-wurud (absolut dari Allah), tetapi ada pengklasifikasian kepada ayat-ayat yang jelas, absolut dan satu artinya (qath'i aldlalalah), dan satu ayat yang bisa mengandung berbagai pengertian (zhanni al-dlalalah). Klasifikasi ayat-ayat yang terakhir ini, yang menimbulkan berbagai mazhab dan aliran dalam Islam. ${ }^{18}$ Pembedaan ini, menuntut sikap toleran dalam menerima pluralitas aliran pemikiran keagamaan. Porsi ini merupakan kavling penafsiran sekaligus ruang ijtihad, dengan pemfungsian rasio secara optimal. Langkah dan strategi dekonstruktif dapat dilakukan dengan dua hal. Pertama, pola pemikiran Islam yang telah melahirkan formulasi tradisi keilmuan Islam harus ditelaah ulang (re-reading) secara benar sebagai upaya membongkar (dekonstruksi) sistem pemikiran (episteme) yang dominan dalam suatu tahap sejarah tertentu. Ini disebut dengan prosedur regresif. Kedua, karena teks yang diderivasi oleh tradisi tersebut kini masih aktif sebagai sistem pengetahuan, maka diupayakan adanya transformasi muatanmuatan dan fungsi awalnya kepada sesuatu yang baru. Ini disebut prosedur progresif.

Sebagai kristalisasi reflektif dari penalaran mujtahid atas teks, hukum Islam selalu sarat dengan muatan ruang dan waktu yang melingkupinya. ${ }^{19}$ Hukum Islam tidak lahir dari yang hampa (eksnihilo), di ruang hampa (innihilo), melainkan terlahir di tengah dinamika pergulatan kehidupan masyarakat sebagai jawaban solusi atas problematika aktual yang muncul. Problematika masyarakat selalu berkembang dan berubah seiring dengan perkembangan dan perubahan masyarakat itu sendiri. Dengan demikian hukum Islam otomatis akan selalu berkembang dan berubah selaras dengan perkembangan dan perubahan waktu dan ruang yang melingkupinya. ${ }^{20}$ Inilah relevansinya hukum Islam dikatakan dinamis, elastis, dan fleksibel karena selaku cocok untuk semua masyarakat walaupun selalu berubah dan berbeda. Perubahan masyarakat dalam berbagai aspeknya baik ekonomi, politik, sosial, budaya dan lain-lain dihadapi oleh hukum Islam dengan semestinya, disongsong dan diarahkan secara sadar bukan dihadapi secara acuh tak acuh, dibiarkan begitu saja.Ini adalah pengejawantahan dari fungsi hukum Islam sebagai pengendali masyarakat (sosial control), perekayasa sosial (sosial engineering) dan pensejahtera sosial (sosial welfare). Dalam hal ini hukum Islam telah memberikan prinsip-prinsip penting mengenai pengembangan yang rasional dalam upaya adaptasi dengan lingkungan barunya. ${ }^{21}$ Melalui pola seperti ini, hukum Islam mampu menghindari terjadinya krisis hukum yang dilematis di tengah publiknya

\footnotetext{
${ }^{17}$ Abdul Manan, Reformasi Hukum Islam di Indonesia, Jakarta, Rajawali Pers, hal.151

${ }^{18}$ Abdul Manan, Reformasi Hukum Islam di Indonesia, Jakarta, Rajawali Pers, hal.151

${ }^{19}$ Sya'ban Muhamad Isma'il, 1985, al- Tasyri' al- Islami, Kairo, Maktabat al-Nahdlah al-Mishriyah, hal. 16.

${ }^{20}$ Fazlur Rahman, 1987, Neo Modernisme Islam, ter. Mizan, Bandung, Mizan, hal.51.

${ }^{21}$ John Donohue dan John L. Esposito, 1984, Pembaharuan Pemikiran dalam Islam, ter. Rajawali, Jakarta, Rajawali Press, hal.72
} 
sendiri. Dengan demikian, peranan hukum Islam akan selalu efektif di tengah masyarakatnya, di manapun dan bagaimanapun modelnya.

Setiap produk pemikiran hukum Islam pada dasarnya adalah hasil interaksi antara si pemikir hukum dengan lingkungan sosio-kultural atau sosio-politik yang mengitarinya. Oleh karena itu produk pemikirannya itu sebenarnya bergantung pada lingkungan tersebut. Pendekatan ini memperkuat alasan dengan menunjuk kepada kenyataan sejarah, bahwa produk-produk pemikiran yang sering dianggap sebagai hukum Islam itu sebenarnya tidak lebih dari hasil interaksi tersebut.

Pendekatan ini menjadi penting sedikitnya karena dua hal, yaitu: Pertama, untuk meletakkan produk pemikiran hukum Islam itu pada tempat yang seharusnya. Kedua, untuk memberikan tambahan keberanian kepada para pemikir hukum Islam sekarang dan masamasa akan datang agar tidak ragu-ragu melakukan pembaharuan dan atau perubahan produk pemikiran hukum karena sejarah telah membuktikan, bahwa umat Islam di berbagai penjuru dunia telah melakukannya tanpa merasa keluar dari hukum Islam. ${ }^{22}$ Untuk membuktikan pernyataan di atas dapat kita cermati dari produk-produk hukum Islam dari masa ke masa. Di kalangan sahabat Nabi Muhammad SAW, Umar bin Khattab termasuk salah satu pemikir hukum Islam yang dalam menetapkan hukum sangat memperhatikan kondisi sosial masyarakatnya. Contoh nyata dalam hal ini misalnya tentang hukum potong tangan bagi pencuri. Hukuman yang diberika kepada pencuri sesuai dengan al-Qur'an adalah potong tangannya. ${ }^{23}$ Akan tetapi Umar bin Khattab pernah membatalkan hukuman potong tangan tersebut pada suatu tahun terjadinya kelaparan. ${ }^{24}$ Argumentasi lain mengatakan bahwa hukuman potong tangan tersebut dibatalkan karena pencurian dilakukan oleh orang yang terdesak mencari makan. ${ }^{25}$ Dengan demikian dapat dipahami bahwa dalam menetapkan sebuah hukum, Umar bin Khattab selalu memperhatikan latar belakang yang menyertai kasus tersebut. Hal ini tentunya dimaksudkan untuk melindungi jiwa manusia terkait dengan kebutuhan darurat yang harus dipenuhinya.

Pembuktian lain juga dapat dilihat tentang bagaimana para ulama fiqh telah dipengaruhi oleh faktor lingkungan sosial budaya dalam menghasilkan karya fiqh mereka. Bukti yang paling banyak dikenal masyarakat adalah riwayat tentang Imam al- Syafi'i yang mempunyai qawl Qadim (pendapat lama) dan qawl jadid (pendapat baru). ${ }^{26}$ Pendapat lama diberikan al-Syafi'i ketika beliau berada di Baghdad dan pendapat baru dikemukakan ketika beliau telah pindah ke Mesir. Selain adanya qawl jadid dan qawl qadim dari al- Syafi'i, terjadinya perbedaan corak fiqh di kalangan madzhab empat juga tidak terlepas dari perbedaan latar belakang kehidupan tokoh masing-masing. Perbedaan-perbedaan produk hukum yang terjadi di kalangan mereka, di samping memang ada karena perbedaan ushul dan thuruq istinbatnya, juga karena adanya perbedaan tuntutan kemaslahatan komunitas akibat perbedaan daerah, waktu, dan budaya. Namun kesemuanya itu akan bertemu pada mata air, yakni pada kaidah-kaidah umum, prinsip-prinsip yang kulli dan universal yang terkandung

\footnotetext{
${ }^{22}$ M.Atho' Mudzhar, 1998, Membaca Gelombang Ijtihad: Antara Tradisi dan Liberalisasi, Yogyakarta, Titian Ilahi Press, hal.105

${ }^{23}$ QS. Al-Maidah (5) : 38

${ }^{24}$ Shubbi Mahmassani, 1981, Filsafat Hukum dalam Islam Jilid 2, ter. Ahmad Sudjono, Bandung: alMaarif, hal. 166

${ }^{25}$ Amir Syarifuddin, 1993, Perubahan Pemikiran Islam, Bandung: Angkasa Raya, hal.98.

${ }^{26}$ Amir Syarifuddin, 1993, Perubahan Pemikiran Islam, Bandung: Angkasa Raya, hal.107
} 
dalam al-Qur'an dan al-Sunnah. ${ }^{27}$ Dengan adanya penjelasan-penjelasan di atas menjadi lebih jelas bahwa agar produk hukum itu dapat dapat mengikuti perkembangan jaman, teraplikasi secara empiris di kalangan masyarakatnya serta dapat menjadi solusi atas persoalan yang muncul di masyarakat maka dalam proses perumusannya, mujtahid tidak hanya dituntut untuk menguasai ushul al ahkam dan thuruq al istinbath, tetapi lebih dari itu juga dituntut untuk mampu mencermati secara jeli tradisi dan aspek-aspek realitas social dan bugaya yang sedang berkembang di masyarakat. ${ }^{28}$ Sebab berijtihad yang hanya mengandalkan dan atau memperhatikan dalil aql dan naql, tanpa memperhatikan perbedaan tradisi, waktu, tempat dan situasi kondisi manusia, maka sungguh ia telah berbuat sesat dan menyesatkan. ${ }^{29}$

Uraian di atas menunjukkan bahwa semangat Hukum Islam dalam menjawab perkembangan masyarakat menunjukkan adanya kesesuaian dengan konsep hukum progresif yang dikenalkan Sacipto Rahardjo. Sebagaimana dijelaskan di muka bahwa Hukum progresif mempunyai empat karakteristik yaitu:

1. Hukumprogresif berpendirian hukum adalah untuk manusia;

2. Hukum progresif menolak untuk mempertahankan statusquo dalam berhukum;

3. Peradaban hukum tertulis akan melahirkan akibat penerapan hukum bekerja seperti mesin. Harus ada cara untuk melakukan pembebasan dari hukum formal;

4. Hukum progresif memberikan perhatian besar terhadap peranan perilaku manusia dalam berhukum. Karena peranan perilaku menentukan teks formal suatu peraturan tidak dipegang secara mutlak. ${ }^{30}$

Jika melihat kepada asas hokum Islam secara umum sebagaimana pendapat dari Hudari Bik, yaitu 'adamulharj (meniadakan kesempitan), taqlil al-taklif (menyedikitkan beban), dan tadarruj fial-tasyri' (berangsur-angsur dalam menetapkan hukum), maka ketiga asas pembangunan hokum Islam itu dekat sekali memiliki kesesuaian dengan karakteristik pertama dari hukum progresif, yaitu hokum untuk manusia. Asas meniadakan kesempitan dan menyedikitkan beban yang juga didukung oleh kaidah fikih yang berbunyi almasyaqqahtajlibal-taysir (kesulitan mendorong kemudahan) dan al-dlararyuzalu (kerusakan harus dihilangkan) menunjukan bahwa syariat Islam memiliki perhatian yang sangat besar terhadap kemudahan dan keringanan hukum bagi manusia. Hal ini berarti, hukum Islam memposisikan hokum bagi kemaslahatan manusia, hal ini sesuai dengan semangat dari hokum progresif, yaitu hukum untuk manusia.

Pembangunan hukum Islam juga sangat memperhatikan perilaku manusia dalam berhukum sebagaimana salah satu karakteristik dari hukum progresif (karakteristik keempat). Hal ini dibuktikan dengan adanya asas berangsur-angsur dalam mendatangkan hukum. Contoh dari penerapan asas ini adalah mengenai pengharaman khamar yang tidak sekaligus turun dalam satu kali perintah, melainkan beberapa kali. Hal ini dikarenakan untuk menghindari penolakan secara radikal dari masyarakat yang menjadi objek perintah ini. Karena masyarakat ketika itu sudah terbiasa meminum khamar sehingga sulit utnuk

\footnotetext{
${ }^{27}$ Sjechul Hadi Permono, 2002, Dinamisasi Hukum Islam dalam Menjawab Tantangan Era Globalisasi, Demak, Demak Press, hal. 21

${ }^{28}$ Musthafa Abd al-Rahim Abu Ujailah, al-urf wa Atsaruhfi al Tasyrial-Islami, 1986, Tripoli: Dar alKutub al-Wathaniyah, hal.236

${ }^{29}$ Abd al-Mun'im al-Naml, 1984, Al Ijtihad, tt: Dar al-Syuruq, hal.75

${ }^{30}$ Rangkuman karakteristik ini juga terdapat pada artikel Mukhtar Zamzami, Mencari Jejak Hukum Progresif dalam system Khadi Justice, Varia Peradilan, tahun XXIV No.286 (September 2009), hal.23
} 
merubahnya sekaligus. Maka mengingat perilaku masyarakat yang demikian, maka hukum keharaman khamar tidak turun dalam sekali waktu saja. Selanjutnya, terkait dengan karakteristik kedua dari hukum progresif yang menolak adanya statusquo dalam berhukum, maka menurut penulis, karakteristik ini sesuai dengan adanya ijtihad di dalam fikih. Alasan logis dari adanya ijtihad adalah dikarenakan setiap masalah berbeda-beda tergantung tempat waktu maupun kondisi yang melingkupinya dan selalu muncul masalah-masalah baru yang membutuhkan jawaban segera. Menganggap bahwa semua permasalahan telah dijawab oleh kitab-kitab fikih menurut penulis adalah sama dengan memposisikan kitab-kitab fikih dalam status quo.

Dalam konteks Indonesia, maka gagasan para tokoh di Indonesia yang berusaha menyingkirkan anggapan bahwa ijtihad telah tertutup dan menggagas fikih yang berkepribadian Indonesia bias digolongkan kepada penerapan asas menolak statusquo dalam berhukum. Peranan ijtihad sangat besar dalam perkembangan dan pembaruan hukum Islam di Indonesia. Langkah awal yang dilaksanakan oleh para pembaru hokum Islam di Indonesia adalah mendobrak paham ijtihad telah tertutup, dan membuka kembali kajian-kajian tentang hokum Islam dengan metode komprehensif yang sesuai dengan kebutuhan masyarakat. Fikih yang dihasilkan oleh mujtahid pada masa lalu adalah suatu karya agung yang dapat memandu kehidupan umat dalam segalabi dangnya, karena ia dipahami dan dirumuskan sesuai dengan keadaan dan kondisi pada masa itu. Namun waktu, kondisi dan tempat yang dihadapi umat sekarang sudah berbeda dengan waktu, kondisi dan tempat dirumuskannya fikih tersebut. Oleh karena itu, fikih lama itu secara tekstual sulit dijadikan panduan kehidupan beragama secara utuh pada saat ini. Karenanya fikih lama sulit diterapkan pada saat ini, sedangkan umat sangat membutuhkannya. ${ }^{31}$ Hampir di seluruh umat Islam sudah berpikir untuk mengaktualkan hukum Islam dengan cara memahami semua hukum Islam untuk menghasilkan rumusan baru sehingga dapat menjadi panduan dalam kehidupan nyata.

Gagasan agar fikih yang diterapkan di Indonesia harus berkepribadian Indonesia dicetuskan oleh Hasbi ash-Shiddieqy. Menurut Hasbi ash-Shiddiqy, dalam rangka pembaruan hukum Islam di Indonesia perlu dilaksanakan metode talfiq $^{32}$ dan secara selektif memilih pendapat mana yang cocok dengan kondisi Negara Indonesia. Disamping itu perlu digalakkan metode komparasi. ${ }^{33}$ Kajian komparasi ini hendaknya dilakukan juga dengan hukum adat dan hukum positif Indonesia, juga dengan syari'at agama lain. Sehubungan dengan hal ini, seorang yang ingin melakukan kajian komparasi hendaknya mempunyai pengetahuan yang luas dalam berbagai ilmu pengetahuan dan juga mengetahu isecara lengkap tentang berbagai masalah fikih. Gagasan ini mendapat sambutan positif dari berbagai pihak para pembaru hukum Islam di Indonesia, baik secara perorangan maupun secara organisasi. Di Indonesia

\footnotetext{
${ }^{31}$ AmirSyarifuddin, 2002, Meretas Kebekuan Ijtihad, (Ed) Abdul Halin, Jakarta, Ciputat Press, hal.76

${ }^{32}$ Yang dimaksud dengan talfiq adalah meramu beberapa pemikiran atau ijtihad ulama terdahulu, sehingga dengan ramuan ini muncul satu bentuk lain yang kelihatannya baru. Hal ini ditempuh karena bila diambil dari satu mazhab tertentu dalam menghadapi suatu masalah terlihat ada hal-hal yang tidak aktual. Fikihfikih yang ada ini disamping mengandung hal-hal yang sudah tidak actual masih banyak pula mengandung bagian-bagian yang bersif ataktual. Bagian-bagian yang mengandung daya aktual dari beberapa aliran fikih itu digabung menjadi satu hingga masalahnya dalam bentuk keseluruhan menjadi aktual dalam arti mengandung nilai-nilai maslahat.

${ }^{33}$ Yaitu metode memperbandingkan satu pendapat dengan pendapat lain dari seluruh aliran hokum yang ada atau yang pernah ada, dan memilih yang lebih baik dan lebih dekat kepada kebenaran serta didukung oleh dalil yang kuat.
} 
dikenal beberapa orang pembaru hokum Islam yang banyak memberikan kontribusi dalam perkembangan hukum Islam, diantaranya Hasan Bangil, Harun Nasution, Hazairin, Ibrahim Husen, Munawir Syadzali, Busthanul Arifin dan lain-lain. Para tokoh ini berjasa begitu besar dalam perkembangan hokum Islam di Indonesia terutama dalam hal memasukkan nilai-nilai hokum Islam ke dalam legalisasi nasional dan juga ide lahirnya beberapa peraturan perundang-undangan untuk dipergunakan oleh umat Islam pada khususnya dan warga Negara Indonesia pada umumnya.

Disamping itu, organisasi Islam seperti Nahdhatul Ulama, Muhammadiyah, Persatuan Islam (Persis), Jamiatul Wasliyah, al-Irsyad, Majelis Ulama Indonesia (MUI) dan Ikatan Cendikiawan Muslim Indonesia (ICMI) telah banyak memberikan kontribusi yang sangat besar terhadap pembaruan hokum Islam di Indonesia dan telah berusaha semaksimal mungkin agar hokum Islam dapat masuk ke dalam legalisasi hokum nasional. Fleksibelitas perkembangan pemikiran hukum Islam di Indonesia sangat relevan dengan memperkenalkan etos progresivisme dalam dinamika dan kristalisasi hukum Islam. Implikasi dari corak pemikiran progresif ini adalah pembebasan manusia dari hal-hal yang bersifat mitologis, pasif maupun agresif-konservatif. Atas dasar etos progresif ini, diakui kapasitas manusia yang memiliki segenap kebebasan (free).

\section{KESIMPULAN}

Menurut Prof. Satjipto Rahardjo, hukum progresif adalah serangkaian tindakan yang radikal, dengan mengubah sistem hukum (termasuk merubah peraturan-peraturan hukum bila perlu) agar hukum lebih berguna, terutama dalam mengangkat harga diri serta menjamin kebahagiaan dan kesejahteraan manusia, melakukan pembebasan, baik dalam cara berpikir maupun bertindak dalam hukum, sehingga hukum itu mampu menuntaskan tugasnya mengabdi kepada manusia. Karena hukum itu bukan hanya bangunan peraturan, melainkan juga bangunan ide, kultur, dan cita-cita. Kemudian bahwa antara gagasan hukum progresif dan hukum Islam memiliki kesesuaian yang dapat diuraikan dengan dua poin penting. Jika dilihat dari asas-asas hukum Islam secara umum, maka asas-asas hukum Islam tersebut memiliki kesesuaian dengan karakteristik hukum progresif, yaitu hukum untuk (kepentingan) manusia. Sedangkan ijtihad sebagai cara untuk menjadikan hukum Islam sesuai dengan setiap zaman adalah sesuai dengan karakteristik menolak mempertahankan status quo dalam berhukum.

\section{DAFTAR PUSTAKA}

Abdul Aziz Dahlan, Ensiklopedi Hukum Islam, Cet. I, Jilid 6, Jakarta, Ichtiar Baru Van Hoeve.

Abdul Manan, 2013, Reformasi Hukum Islam di Indonesia, Jakarta, Raja Grafindo Persada. Abu Ishaq Asy Syatibi, 2005, Al Muwafaqat fi Ushul al Syari'ah, Lebanon, Dar al Kutub al Ilmiyah.

Ahmad Rofiq, 1995, Hukum Islam di Indonesia, Jakarta, Raja Grafindo Persada.

Al-Ghazali, Abu Hamid, Al-Mustashfa, Mesir, Maktabah Al-Jundi. 
Asmawi, 2012, Studi Hukum Islam dari Tektualis-Rasionalis sampai Rekonsiliatif, Yogyakarta, Teras.

Atho Mudzhar, 2014, Esai-Esai Sejarah Hukum Islam, Yogyakarta, Pustaka Pelajar. Daud Ali, 1983, Asas-Asas Hukum Islam, Jakarta, Balai Pustaka.

Dede Rosyada, 1995, Hukum Islam dan Pranata Sosial, Jakarta, Raja Grafindo Persada.

Esmi Warrasih, 2015, Pranata Hukum sebagai Telaah Sosiologis, cet. ke 5, Semarang, Pustaka Magister.

Faisal, 2015, Pemaknaan Hukum Progresif, Yogyakarta, Thafa Media.

Fathurrahman Djamil, 1999, Filsafat Hukum Islam, Cet. III, Jakarta, Logos Wacana Ilmu.

Ismail Muhammad Syah dkk, 1992, Filsafat Hukum Islam, cet.2, Jakarta, Bumi Aksara bekerjasama dengan Direktorat Jenderal Pembinaan Kelembagaan Agama Islam Departemen Agama.

Jasim Hamidi, 2011, Hermeneutika Hukum, Sejarah-Filsafat \& Metode Tafsir, Malang, Universitas Brawijaya Press.

Jasser Auda, 2008, Membumikan Hukum Islam Melalui Maqashid Syariah, Terj. Rosidin dan 'Ali ‘Abd el-Mun’in, Bandung, Mizan Pustaka.

Juhaya S. Praja, 1991, Hukum Islam di Indonesia, Bandung, Remaja Rosdakarya. Khisni, 20015, Perkembangan Pemikiran Hukum Islam, Semarang Unissula Press.

Moh. Mahfud MD dkk, 2013, Dekonstruksi dan Gerakan Pemikiran Hukum Progresif, Yogyakarta, Thafa Media.

Muhammad Hasbi Ash Shiddieqy, 1990, Falsafah Hukum Islam, Jakarta, Bulan Bintang.

Muhammad Iqbal, 2009, Hukum Islam Modern Dinamika Pemikiran dari Fiqh Klasik ke Fiqh Indonesia, Tangerang, Gaya Media Pratama.

Muhammad Qawwas Qal'ahji, 1999, Ensiklopedi Fiqh Umar bin Khaththab, terjemahan M. Abdul Mujieb, AS, dkk, cet. I, Jakarta, RajaGrafindo.

Muhammad Roy Purwanto, 2014, Dekonstruksi Teori Hukum Islam, Yogyakarta, Kaukaba Dipantara.

Muhammad Syukri Albani Masution, 2013, Filsafat Hukum Islam, Jakarta, Rajawali Pers.

Nurcholis Madjid, 1992, Islam Doktrin dan Peradaban; Sebuah Telaah Kritis tentang Masalah Keimanan, Kemanusiaan dan Kemodernan, Jakarta, Yayasan Wakaf Paramadina.

Pujiono, 2012, Hukum Islam dan Dinamika Perkembangan Masyarakat, Yogyakarta, Mitra Pustaka.

Qodri Azizy, 2002, Aklektisisme Hukum Nasional, Yogyakarta, Gama Media. 
105 Mamba'ul 'Ulum, Vol. 17, No. 2, Oktober 2021: 95-105

Sadzali Musthafa, 1989, Pengantar dan Azas-azas Hukum Islam di Indonesia, Cet.I, Solo, CV. Ramadhani.

Saifullah, 2013, Refleksi Sosiologi Hukum, Cet 3, Bandung, Refika Aditama.

Sudikno Mertokusumo, 2014, Teori Hukum, Yogyakarta, Cahaya Atma Pustaka.

Suteki, 2015, Masa Depan Hukum Progresif, Yogyakarta, Thafa Media.

Teguh Prasetyo dan Abdul Halim Barkatullah, 2014, Filsafat, Teori, dan Ilmu Hukum; Pemikiran Menuju Masyarakat yang Berkeadilan dan Bermartabat, Jakarta, Rajawali Pers.

Wahbah Az-Zuhaili, 1984, Al Fiqhul Islam Wa Adillatuh, Jilid 8, Damaskus-Syuriah Daarul Fikri.

Yunahar Ilyas, 2015, Dialektika Pemikiran Islam dari Klasik hingga Modern, Yogyakarta, Itqan Publisting. 